\title{
Lépéskényszerben - új feladatok az életveszélyes perioperatív vérzések ellátásában
}

\author{
Babik Barna dr. ${ }^{1}$ - Fazakas János dr. ${ }^{2}$ \\ Matusovits Andrea dr. ${ }^{3}$ - Fülesdi Béla dr. ${ }^{4}$ \\ ${ }^{1}$ Szegedi Tudományegyetem, Általános Orvostudományi Kar, \\ Aneszteziológiai és Intenzív Terápiás Intézet, Szeged \\ ${ }^{2}$ Semmelweis Egyetem, Általános Orvostudományi Kar, Transzplantációs és Sebészeti Klinika, Budapest \\ ${ }^{3}$ Országos Vérellátó Szolgálat, Budapest
}

${ }^{4}$ Debreceni Egyetem, Általános Orvostudományi Kar, Aneszteziológiai és Intenzív Terápiás Klinika, Debrecen

\begin{abstract}
Az életveszélyes periprocedurális vérzések növelik a perioperatív morbiditást és mortalitást, és koncentrált terhet rónak az egészségügyi betegellátó rendszer humán- és anyagi erőforrásaira. A nemzetközi transzfuziológiai gyakorlatban 2009 óta csökken a transzfúzióra került allogén készítmények mennyisége, ami a perioperatív vértakarékossági program és az életveszélyes perioperatív vérzések ellátására vonatkozó új innovációk térnyerésének köszönhető. A progreszszív elemek adaptálása megkerülhetetlen feladatokat ró a magyarországi betegellátó rendszer gyógyítói és múködtetői oldalára. A súlyosan vérző betegek ellátásának legfontosabb új elemeit a stabil koagulációsfaktor-koncentrátumok első vonalbeli használata, a betegágy melletti viszkoelasztikus véralvadási tesztek és az irányelvek együttes alkalmazása képezi. Napjaink és a közeljövő másik, a betegellátás teljes vertikumát átható problémáját a fenyegető vérkészítmény-ellátási nehézségek jelentik. Az életveszélyes perioperatív vérzések ellátásához kapcsolódó diagnosztikus és terápiás modalitások részben új erőforrásokat igényelnek, de az allogén készítményekre és a faktorkoncentrátumra fordítható pénzügyi keretek intézeti/intézményi szintű, országosan szervezett átjárhatóvá tételével megteremthetnénk a faktorkoncentrátumok első vonalbeli használatának anyagi lehetőségét, és jelentős vérmegtakarítást érhetnénk el.

Orv Hetil. 2019; 160(6): 203-213.
\end{abstract}

Kulcsszavak: masszív vérzés, masszív transzfúzió, haemostasisresuscitatio, fibrinogén, faktorkoncentrátumok, viszkoelasztikus véralvadási tesztek

\section{Forced steps for making improvements in severe perioperative haemorrhage}

Severe perioperative bleeding increases perioperative morbidity and mortality. The management of the consequences imposes high burden on the human and financial resources of healthcare providers. Since 2009, there has been a continued worldwide decline in demand for allogenic blood products. This tendency can mainly be attributed to Perioperative Blood Management Program and to new innovative management applying haemostatic factor concentrates, viscoelastic assays and guidelines for treatment of the severe periprocedural bleeding patients. One of the major challenges of our times is still to match blood supply with demand. The new diagnostic and therapeutic modalities for managing the bleeding patients require new financial resources on the one hand and, on the other hand, call for redistribution of the material means provided by the health care system. Achieving interoperability between financial resources allocated to allogenic blood products and factor concentrates, the current state-of-the-art approach for managing the bleeding patient can be used to save blood and the lives of patients simultaneously.

Keywords: massive bleeding, massive transfusion, haemostatic resuscitation, fibrinogen, factor concentrates, viscoelastic haemostatic tests

Babik B, Fazakas J, Matusovits A, Fülesdi B. [Forced steps for making improvements in severe perioperative haemorrhage]. Orv Hetil. 2019; 160(6): 203-213.

(Beérkezett: 2018. szeptember 26.; elfogadva: 2018. október 27.)

A Szerkesztőség felkérésére készített tanulmány 


\section{Rövidítések}

aPTI = aktivált parciális tromboplasztinidő; $\mathrm{CPB}=$ (cardiopulmonary bypass) cardiopulmonalis bypass; EMMI = Emberi Erőforrások Minisztériuma; FFP $=($ fresh frozen plasma) friss fagyasztott plazma; HBCS = homogén betegségcsoportok; $\mathrm{MT}=$ masszív transzfúzió; $\mathrm{MV}=$ masszív vérzés; $\mathrm{NOAC}=$ (novel oral anticoagulant) új orális alvadásgátló szerek; PBM = (patient blood management) vérmentő betegkezelés program; $\mathrm{PCC}=$ (prothrombin complex concentrate) protrombinkomplex-koncentrátum; $\mathrm{PI}=$ protrombinidő $; \mathrm{POC}=($ point-of-care $)$ mütőasztal/betegágy melletti; PRCT $=$ (prospective randomized controlled trial) prospektív, randomizált, kontrollált vizsgálat; $\mathrm{RBC}=($ red blood cell $)$ vörösvérsejtmassza; THR = thrombocytaszuszpenzió; VHA $=$ (viscoelastic haemostatic assays) viszkoelasztikus haemostaticus vizsgálatok

Az életveszélyes periprocedurális vérzések megfelelő ellátása az egyes betegek és az egészségügyi ellátórendszer szempontjából egyaránt alapvető jelentőségứ. A napjainkban elérhetố új diagnosztikus és terápiás modalitások szakmai, logisztikai változtatásokat tesznek szükségessé a betegellátás gyakorlati és fenntartói oldaláról egyaránt.

\section{Életveszélyes periprocedurális vérzések: megjelenés klinikai fókuszpontokban}

Életveszélyes periprocedurális vérzéseknek nevezzük azokat a perioperatív, traumás vagy peripartum masszín vérzéssel $(M V)$ és következményes massziv transzfúzióval $(M T)$ járó állapotokat, melyek szöveti sérülés, vérzéses sokk és következményes, akut coagulopathia révén további szövődmények fellépését, szerv- és/vagy életvesztés veszélyét hordozzák magukban. A következmények sokszor gyógyítható alapbetegségben szenvedő betegeket érintenek, ső́t a szövődmények és/vagy elhalálozás akár fiatal, eredendően nem beteg egyéneket is fenyegethet trauma vagy szülés során. A szívsebészeti betegellátásban a nagy tömegú vérzések előfordulása 2-24\% [13 ]. A súlyos traumát szenvedett betegek 15\%-ában fordul elő erőteljes vérzés, mely a poszttraumás halálozás $40 \%$ áért tehető felelőssé [4], ezzel a nem kellően kontrollált vérzések a sérült betegek potenciálisan megelőzhetô haláleseteinek vezető okává lépnek elő [5]. A szülészeti masszív vérzések az anyai halálozás 25-30\%-ához járulnak hozzá közvetlenül [6,7]. Előfordulási gyakoriságuk világszerte nő, az ezredfordulón jellemző $0,1 \%$-os incidencia 10 évvel később már 2,6-11,4\%-ra emelkedett [6]. A nagyságrendi növekedés mögött a kiterjedt oxitocinhasználat és a következményes uterusatonia, valamint a császármetszések növekvő aránya állhat, ezért a fejlődó és a fejlett világot egyaránt érintik. A peripartum masszív vérzések jelentős növekedése természetszerúleg magával vonja a peripartum anyai morbiditás növekedését, ezen belül az életmentő hysterectomiák gyakoribbá válását is [7].

A súlyos vérzéses szövődményt szenvedett szívsebészeti, traumatológiai, szülészeti, érsebészeti, ortopédiai betegek száma a teljes betegszámhoz képest viszonylag alacsony, ellátásuk azonban jelentős emberi és anyagi erőforrást köt le. A teljes transzfúziós kontingens 10$20 \%$-át a szív-mellkas sebészetben használják fel $[8,9]$, ennek a nagy mennyiségnek a $90 \%$-át viszont csak a betegek $10 \%$-a kapta. Ez a koncentrált transzfúziós igény jelzi az adott eset ellátásának gyakorlati nehézségeit, de fontos pozitív üzenetet is hordoz: ha ezekben a klinikai helyzetekben szakmailag, logisztikailag előre tudunk lépni, akkor jelentôs haladást érhetünk el az életveszélyes perioperatív vérzések ellátásában, valamint az emberi és anyagi erőforrások kímélésében.

\section{Teher a betegen, teher az ellátórendszeren}

A vérzéses szövődmények növelik a perioperatív morbiditást. Nagyobb a veszélye a reoperációnak, a stroke-nak, az elhúzódó posztoperatív lélegeztetésnek és a mútét utáni intenzíves tartózkodásnak. Nagyobb a 30 napon belüli mortalitás $[1,2,10]$.

A súlyos periprocedurális vérzések természetszerúleg vonják magukkal a kórházi költségek emelkedését. A szívsebészetben a súlyos vérzéses szövődményt elszenvedő betegek ellátása a költségek megkétszereződésével járt ( 15 400 versus $\sim 8500$ euró) [11]. A súlyosan vérző traumás betegek elsődleges kórházi ellátására fordított átlagos költség 2010-ben átszámítva mintegy 7 millió forint volt, melynek $62 \%$-át a lélegeztetésre, az intenzív osztályos és osztályos ellátásra kellett fordítani, magának a sebészeti beavatkozásnak a költsége csak a teljes összeg 16\%-át tette ki [12]. A vérző betegek ellátásához szükséges anyagi erőforrások mennyisége elöreláthatóan tovább fog növekedni [12] a sérültek magasabb kora és több társbetegsége, tehát a betegeket egyre inkább jellemző morbiditási hajlam („esendőség”, „esékenység”, frailty) miatt [13-15].

A MV a teljes vértérfogat 24 óra alatti, a vértérfogat felének 3 óra alatti elvesztését jelenti, illetve rövidebb távon a $150 \mathrm{ml} /$ perc, esetleg a 20 percen át történő, 1,5 $\mathrm{ml} /$ perc/kg vérzést foglalja magában, míg a MT-n a teljes vértérfogat 24 óra alatti kicserélését, pótlását értjük. A MV és a MT alapjaiban befolyásolja a mortalitási, valamint a rövid és hosszú távú morbiditási eseményeket (az „egyén sorsát”), valamint ezek rövid és hosszú távú költségvonzatait (az „ellátórendszer sorsát”). Másképp fogalmazva: a súlyosan vérző beteg minél optimálisabb perioperatív ellátásával az egészségügybe már bekerült, illetve az egészségügy túlterheltsége miatt abba késve bejutott vagy egyáltalán be nem került egyén sorsát is befolyásoljuk.

A súlyos periprocedurális vérzések hozzájárultak ahhoz a világszerte jelentkező tendenciához, hogy a transzfúziós beavatkozások száma 1997 és 2008 között 50\%kal megnőtt (1.ábra). A transzfúziós készítmények hic et nunc biztosítása, a természetes veszteségek csökkentése intenzív szakmai, kreatív donortoborzási és pontos adminisztrációs feladatot jelentett a nemzeti és az egyéb 
szervezőelvek mentén múködő vérellátó szolgálatoknak [16]. Az összetett feladatnak a magyar Országos Vérellátó Szolgálat is tradicionálisan és maradéktalanul eleget tett és tesz, és komoly logisztikai és (infra)strukturális fejlesztéseket végzett annak érdekében, hogy mindenkor meg tudjon felelni a betegek és a klinikusok igényeinek.

\section{Perioperatív szakmai kihívás: csökken az allogén transzfúziós készítmények felhasználása a fejlett országokban}

A nemzetközi transzfuziológiai gyakorlatban 2009-ben markáns fordulópont jelent meg: csökkenésnek indult a transzfúzióra került allogén készítmények mennyisége, ami érvényes a vörösvérsejt-koncentrátumra, friss fagyasztott plazmakészítményre, thrombocytaszuszpenzióra egyaránt [16, 17]. A vörösvérsejtkoncentrátumtranszfúzió csökkenésének üteme 2009 óta napjainkig egyenletes, sőt a tendencia erőteljesebb, mint az azt megelőzó évtizedben a növekedés volt [16] (1. ábra). Az Amerikai Egyesült Államokban jelenleg a transzfundált vörösvérsejt-koncentrátum mennyisége mára megegyezik az 1997. évi gyakorlatnak megfelelő értékkel, miközben az elmúlt 20 évben a sebészet és ezzel párhuzamosan a perioperatív terápia mennyiségi expanziója és spektrumának szélesedése természetszerúleg folytatódott. Az új tendencia fel-, meg- és elismerése, valamint az innovatív elemek adaptálása szakmai kihívást és megkerülhetetlen feladatokat jelent a magyarországi operatív, aneszteziológiai és intenzív terápiás, valamint a transzfuziológiai ellátórendszerek gyógyítói és múködtetői oldala számára.

\section{A csökkenö vérfelhasználáshoz vezető okok}

A vérfelhasználás mérséklődése átgondolt innovatív törekvések együttes hatásának következménye, melyek interdiszciplináris megközelítéssel értelmezhetők a Patient Blood Management (PBM) multimodális koncepció keretein belül [18], melyet szabad, de lényegre törő és célzatos fordításban Nemzeti Véradó és Vérmentő Programként lehetne a magyar olvasókhoz közelebb vinni. A PBM három alapvető elven nyugszik: a beteg vörösvértesttömegének optimalizálása, a vérveszteségek csökkentése és a kontrollált anémia által megengedett tartalékok maximális kihasználása. A megfelelő elektív műtéti előkészítés, szükség esetén prehabilitáció [19], a kisebb szöveti traumával járó, kevésbé invazív sebészi technikák, a perioperatív vérdonáció, az eszközös vérmentő módszerek egyre szélesebb körü alkalmazása, az alacsonyabb, ugyanakkor mindig individuálisan megítélendő anémiaküszöb elterjedése fontos általános vértakarékossági elemmé vált.

A MV/MT akut klinikai szituációjában a periprocedurális ellátás a PBM logikáját követi, de hangsúlyaiban szükségképpen átrendezett. Több fontos, önálló, egy-

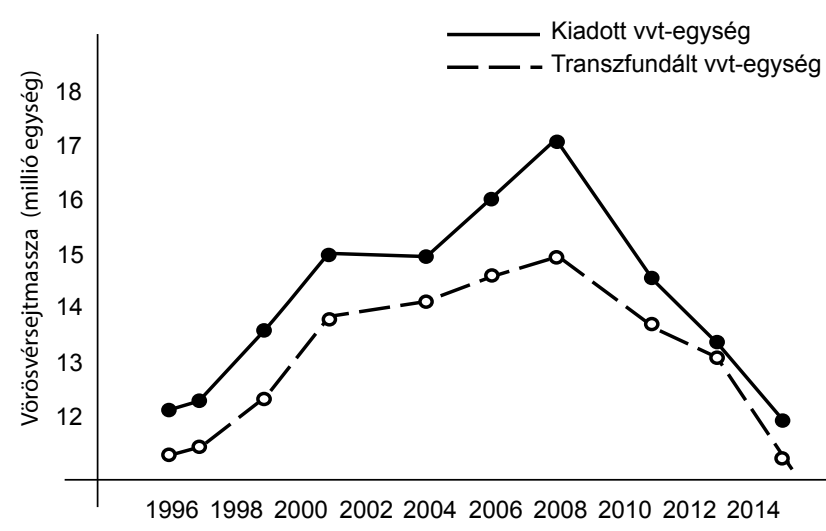

1. ábra

A vérellátó szolgálatok által kiadott és az intézmények által ténylegesen transzfúzióra került vörösvérsejtmassza mennyisége az Amerikai Egyesült Államokban az 1990-es évek második felétől erőteljes növekedést mutatott 2008 -ig, ezután azonban a betegellátás számára rendelkezésre bocsátott és a transzfundált vérmennyiséget egyaránt markáns, monoton csökkenés jellemezte

mással többszörösen kapcsolódó eljárási elem épült be a klinikai gyakorlatba, melyek mindegyike hozzájárult a 2008 utáni évek tendenciájához. Paradigmaváltással állunk szemben, melynek a legfontosabb diagnosztikus és terápiás, taktikai és stratégiai újításai a következők.

1. Stabil koagulációsfaktorkoncentrátum-készítmények széles körü elérhetősége

A MV/MT azonnali és hatékony prokoagulációs szubsztitúciós kezelésének koncepciója a véralvadás két sérülékeny fiziológiai kulcspontján kínál gyakorlatba ültethető lehetőséget; napjainkra a klinikai transzláció mindkettő vonatkozásában megoldott. Az egyik élettani haemostaticus fókuszpontot a fibrinogén jelenti, mely a protrombotikus folyamatok tárgya, és az alvadékképződés alternatíva nélküli alanya [20]. A fibrinogén az alvadási faktorok abszolút mennyiségének döntő hányadát adja [9], s mivel mindenkori teljes mennyisége az érpályában van, a szervezet nem rendelkezik tartalékkal, mennyisége a leghamarabb csökken kritikus szintre vérzés folyamán [21-24]. A fibrinogén teszi lehetővé a vérlemezkék aggregációját, kapcsolatot teremtve a thrombocyta IIb-IIIa receptorok között. A magas fibrinogénkoncentráció sưrû fibrinhálóval ezért funkcionálisan kompenzálni képes a thrombocytopathia és/vagy thrombocytopenia hatását [9, 25-29]. A másik vulnerábilis pontot a trombingeneráció alkotóelemei képezik, tehát a II-es, VII-es, IX-es és X-es alvadási faktorok. Ha ezen a két fiziológiás ponton hatékony szubsztitúcióval, időben és egyszerre beavatkozunk, akkor megteremtjük a koagulációs folyamat egymást követő fő lépéseinek feltételeit. A stabil prokoaguláns farmakológiai készítményekkel (fibrinogénnel és a PCC-vel) végzett haemostasisresuscitatio számos elónyt kínál a labilis prokoaguláns vérkészítmények (FFP) használatával szemben. A gyógyszerek kis térfogatot jelentenek, 
ezért vese- és szívbetegek számára előnyösek, a hígulás vörösvérsejt és thrombocyta vonatkozásában nem számottevő, gyorsan elérhetők, vércsoportfüggetlenek, immunválaszt nem okoznak, és jól standardizálhatók [30-32].

A fibrinogénkoncentrátum tisztított, vírusinaktivált allogén vérplazmából frakcionálással előállított prokoagulációs készítmény. A por halmazállapotú hatóanyag feloldása után 1 g/50 ml koncentrációjú készítményt kapunk, ennek koncentrációja 10-szerese a humán plazmának, illetve FFP-nek ( 2 g/1). A fibrinogént a 2000-es években kezdték kiterjedtebben alkalmazni a perioperatív súlyos vérzések kezelésére. Az évtized második felében szórványos, leíró vizsgálatok jelezték hatékonyságát [33-35]. A 2010-es években robusztus vizsgálati adatok támasztották alá, hogy a fibrinogénkoncentrátum gyorsan és effektíven csökkenti a vérzést, és megelőzheti a coagulopathiából fakadó másodlagos masszív vérzést és a következményes masszív transzfúziós igényt [35-41]. Az ezekből öszszegzett, szisztémás áttekintő vizsgálatok megerősítették, hogy a fibrinogén csökkenti az allogén vérkészítmények felhasználását [42-44]. A készítmény a fertőzések átvitele és a teoretikus protrombotikus mellékhatások tekintetében biztonságos [45]. Magyarországon 1998 óta elérhető.

A protrombinkomplex „poolozott”, tisztított allogén vérplazma cryoprecipitatum felülúszó frakciójából ioncserélő kromatográfiával előállított prokoagulációs készítmény [46]. A PCC II-, VII-, IX- és X-faktort, valamint a protein $\mathrm{C}$ - $\mathrm{t}$, $-\mathrm{S}$-t és kevés heparint tartalmaz kiegyensúlyozott formában, prokoaguláns túlsúllyal [47]. A reszuszpendált oldat faktorkoncentrációja 25-szöröse a fiziológiás plazmaértéknek [48]. A PCC indikációját elsősorban kumarinterápia, vagy májkárosodás miatt K-vitamin-dependens alvadási faktorok hiánya következtében vérző vagy sürgős mútétre kerülő beteg ellátása képezi $[5,30,31,47]$. Indikációt képez még a súlyos, a vérvolumen 150200\%-ának elvesztésével járó, tehát jelentős szerzett faktorhiányt jelentő perioperatív vérzés [24, 25, 35].

2. Mütőasztal/betegágy melletti (POC) viszkoelasztikus véralvadási tesztek terjedése

A mútőasztal/betegágy melletti, vagy point-of-care (POC) véralvadási tesztekhez ma elsősorban a viszkoelasztikus haemostaticus vizsgálatokat (VHA), valamint az impedanciaaggregometriás thrombocytafunkciós vizsgálatokat soroljuk. A VHA-k más oldalról képezik le a haemostasis folyamatát, mint a tradicionális tesztek, és jobban megközelítik a haemostasis természetes funkcionalitását, mert a teljes vér alvadási képességét vizsgálják, és az elsődleges végpont élettanilag „messzebb van”: ezt a kész, „múködo” alvadék, sőt annak esetleges feloldódása képezi [49]. A VHA-k dinamikusak, amennyiben egy múködő élettani folyamat egyes fázisait több aspektusból elkülönítetten kvantifikálják [50]. A VHA-k gyorsak, ezért hasznosak a MV/MT változó körülményei között [23]. A VHA segítségével farmakológiailag befolyásolt, modellezett vizsgálatokat is végezhetünk [51-53], és betanított személyzettel a POC-tesztekre vonatkozó általános elvek [54] mellett biztonságosak [55]. $\mathrm{Az}$ impedanciaaggregometriás thrombocytafunkciós vizsgálatok a primer haemostasis zavarainak célzott diagnosztikájával segítik a MV/MT ellátását.

\section{Szakmai irányelvek}

A traumához kapcsolódó vérzések ellátásáról 2005ben áttekintő közlemény született [56], melyre alapozva 2007-ben európai szakmai irányelv jelent meg [57]; ez utóbbit 2010-ben, 2013-ban és 2016-ban, tehát az általános gyakorlatnál gyakrabban frissítették $[5,58,59]$. Az egymást követő irányelvek ajánlásai a faktorkoncentrátumok, VHA-k és a célvezérelt haemostasisresuscitatio vonatkozásában markáns evolúciót mutatnak (1. táblázat).

A 2005-ben megjelent áttekintő közleményből [56] két fontos tény emelhető ki. Az egyik az, hogy ez a közlemény még a vérfelhasználás növekvő időszakában született, így kontrollként szolgáló elveket tükröz, például lehet korán adni FFP-t, de annak mennyiségéről még nem is nyilatkozik, és fibrinogén adását is csak igen alacsony küszöbérték mellett látja szükségesnek. A másik, hogy a közleményt jegyző két szerző volt rendre a következó évtizedben a későbbi irányelvek és így változások megfogalmazója, növelve a sarokpontok későbbi folyamatos átértékelésének jelentőségét. A 2007-es irányelv [57] már adott iránymutatást a FFP kezdő dózisára nézve, annak esetleges folytatását tradicionális labordiagnosztikával javasolta követni, és a K-vitamin-antagonisták hatásának sürgős visszafordítására PCC alkalmazását ajánlotta. A 2010-es irányelv [58] kiemelte, hogy masszív vérzés esetén a „damage-control” resuscitatio keretein belül, alvadási faktorpótlásra azonnal FFP-t kell adni, vörösvérsejt-koncentrátumhoz képest magas arányban. A dokumentum a 2000-es évek második felében megjelenő, katonai és civil tapasztalatokra építo, leíró vizsgálatokban alkalmazott [60-62] RBC : FFP : THR 1 : 1 : 1 arányával kapcsolatban megválaszolatlan kérdéseket is megfogalmazott. A 2013-ban kiadott frissítésben [59] a korai faktorpótlásra szolgáló FFP alternatívájaként megjelent a fibrinogénkoncentrátum, és az okfejtő magyarázatban hangsúlyozásra kerül, hogy a gyorsan beadható $2 \mathrm{~g}$ fibrinogén 1 liter FFP-nek felel meg, és ezzel a „timeto-treat" idő jelentősen rövidíthető! A korai jelzőt az irányelv nem szorítja konkrét időhatárok közé, de a "korai folyadékresuscitatio" fogalmának párhuzamos alkalmazásával a haemostasisresuscitatiót is az azonnal megkezdendő, életmentő teendők közé utalja [59]. Ebben a dokumentumban jelent meg először a VHA-k használatának ajánlása a coagulopathiakarakterizálás 
1. táblázat | Súlyos sérülésekhez társuló traumás vérzés és coagulopathia ellátására megjelent, egymást követő európai irányelvekből jól kivehető a faktorkoncentrátumok és a viszkoelasztikus, betegágy melletti haemostaticus tesztek használatának térnyerése. A vezérfonalak egyértelmü üzenete, hogy a masszív vérzések azonnali és masszív haemostasisresuscitatiót igényelnek. Hiányos és nem összerendezett szubsztitúciós, farmakológiai és szupportív terápiával a véralvadás paramétereinek plazmaszintje a normális fiziológiást sem közelíti meg, és a hiányzó láncszemek miatt azok is múködésképtelenek. Menynyiségi és minőségi defektusokkal ezeket a betegeket kezelni lehet, de ellátni nem!

\begin{tabular}{|c|c|c|c|c|c|}
\hline & FFP & Fibrinogénkoncentrátum & PCC & POC-tesztek & Célvezérelt kezelés \\
\hline 2005 & $\begin{array}{l}\text { - Lehet korán adni } \\
\text { - RBC : FFP arány: nincs állás- } \\
\text { foglalás, } \\
2: 3 \text { és } 1: 10 \text { között }\end{array}$ & - Adható, ha <l g/l & - & - & - \\
\hline 2007 & $\begin{array}{l}\text { - Lehet korán adni } \\
\text { - } 10-15 \mathrm{ml} / \mathrm{kg} \text { kezdó dózis, } \\
\text { majd sz. sz. ( } 1 \mathrm{C}) \text {, ha a PI és } \\
\text { a PTI > } 1,5 \times \text { normálérték } \\
\text { - RBC : FFP arány: nincs állás- } \\
\text { foglalás }\end{array}$ & $\begin{array}{l}\text { - Adható, ha <1 g/1 } \\
\text { - Kezdó dózis 3-4 g (1C) }\end{array}$ & $\begin{array}{l}\text { - K-vitamin-antago- } \\
\text { nisták sürgős } \\
\text { visszafordítására } \\
\text { (1C) }\end{array}$ & - & - \\
\hline 2010 & $\begin{array}{l}\text { - Kell korán adni (1B) } \\
\text { - } 10-15 \mathrm{ml} / \mathrm{kg} \text { kezdő dózis, } \\
\text { majd sz. sz. (1C), ha a PI és } \\
\text { a PTI > } 1,5 \times \text { normálérték, } \\
\text { vagy a VHA POC alapján } \\
\text { - RBC : FFP arány: nincs állás- } \\
\text { foglalás, de az } \\
\text { RBC : FFP : Thr } 1: 1: 1 \\
\text { aránnyal kétségeit is kifejezi }\end{array}$ & $\begin{array}{l}\text { - Adható, ha }<1-2 \mathrm{~g} / 1 \text {, } \\
\text { vagy a VHA POC } \\
\text { fibrinogéndeficitet jelez } \\
\text { - Kezdó dózis 3-4 g (1C) }\end{array}$ & $\begin{array}{l}\text { - K-vitamin-antago- } \\
\text { nisták sürgős } \\
\text { visszafordítására } \\
\text { (1B) }\end{array}$ & $\begin{array}{l}\text { - Haemostaticus } \\
\text { terápia vezetésére } \\
\text { lehet (lC) }\end{array}$ & - \\
\hline 2013 & $\begin{array}{l}\text { - Kell korán adni (1B) } \\
\text { - sz. sz., ha a PI és a PTI } \\
>1,5 \times \text { normálérték, vagy a } \\
\text { VHA POC alapján (1C) } \\
\text { - Alternatíva: fibrinogén (1C) } \\
\text { - RBC : FFP arány: legalább } \\
1: 2(2 \mathrm{C}) \\
\text { - FFP hátrányait részletezi, és } \\
\text { jelzi, hogy } 2 \text { g fibrinogén } \\
\text { megfelel } 11 \text { FFP-nek }\end{array}$ & $\begin{array}{l}\text { - Adható, ha }<1-2 \mathrm{~g} / 1 \text {, } \\
\text { vagy a VHA POC } \\
\text { fibrinogéndeficitet jelez } \\
\text { - Kezdó dózis 3-4 g (1C) }\end{array}$ & $\begin{array}{l}\text { - K-vitamin-antago- } \\
\text { nisták sürgôs } \\
\text { visszafordítására } \\
(1 \mathrm{~B}) \\
\text { - A VHA POC } \\
\text { koagulációiniciali- } \\
\text { zálás késést jelez } \\
(2 \mathrm{C})\end{array}$ & $\begin{array}{l}\text { - Coagulopathiakarak- } \\
\text { terizálás, haemostati- } \\
\text { cus terápia vezetése } \\
\text { (1C) }\end{array}$ & - \\
\hline 2016 & $\begin{array}{l}\text { - Kell korán adni (1B) } \\
\text { - sz. sz., ha a PI és a PTI } \\
\text { >1,5× normálérték, vagy a } \\
\text { VHA POC alapján (1C) } \\
\text { - Alternatíva: fibrinogén (1C) } \\
\text { - RBC : FFP arány: legalább } \\
1: 2 \text { (1B) } \\
\text { - Részletezi, hogy fibrinogén- } \\
\text { szintet FFP maximum csak } \\
\text { fenntart, emelni csak } \\
\text { koncentrátummal lehet }\end{array}$ & $\begin{array}{l}\text { - Adható, ha }<1-2 \mathrm{~g} / 1 \text {, } \\
\text { vagy a VHA POC } \\
\text { fibrinogéndeficitet jelez } \\
\text { - Kezdó dózis 3-4 g (1C) }\end{array}$ & $\begin{array}{l}\text { - K-vitamin-antago- } \\
\text { nisták sürgős } \\
\text { visszafordítására } \\
\text { (1B) } \\
\text { - A VHA POC } \\
\text { koagulációiniciali- } \\
\text { zálás késést jelez } \\
\text { (2C) } \\
\text { - NOAC sürgős } \\
\text { visszafordításához } \\
\text { (2C) }\end{array}$ & $\begin{array}{l}\text { - Coagulopathiakarak- } \\
\text { terizálás minél előbb, } \\
\text { haemostaticus } \\
\text { terápia vezetése ( } 1 \mathrm{C} \text { ) }\end{array}$ & - Igen \\
\hline
\end{tabular}

Rövidítések:

aPTI = aktivált parciális tromboplasztinido; FFP = friss fagyasztott plazma; NOAC = új orális alvadásgátló szerek; PCC = protrombinkomplexkoncentrátum; PI = protrombinidő; $\mathrm{POC}=$ mútőasztal/betegágy melletti; $\mathrm{RBC}=$ vörösvérsejtmassza; VHA = viszkoelasztikus haemostaticus vizsgálatok

és a haemostaticus terápia vezetése céljából. A napjainkban érvényes, 2016-ban kiadott irányelvfrissítés egyértelművé teszi, hogy egy súlyosan vérző beteg fibrinogénszintjét a nagy mennyiségú FFP segítségével inkább csak tartani tudjuk, de megemelni, azaz a veszteségeket pótolni csak fibrinogénkoncentrátummal lehet. Ebbe a verzióba emelték be a korai célvezérelt haemostaticus kezelés fogalmát, melynek lényege a kórházba érkezés után azonnal megkezdett, VHAken alapuló, tradicionális vizsgálatokkal kiegészített haemostasisdiagnosztika, valamint a faktorkoncentrá- tumokkal végzett haemostasisresuscitatio, mely a veszteségeket célzottan pótolva kezel, és további veszteségeket megelőz, tehát a masszív vérzés, masszív transzfúzió kuplungot szétkapcsolja, és további vérzés szekunder prevenciójának tekinthető. Minél hamarabb rendezzük a hiányállapotot, annál több további vérzést és következményes transzfúziós beavatkozást előzünk meg! A korai célvezérelt haemostaticus kezelés jobban az egyénre és betegségének aktuális állapotára szabott, mint a formulavezérelt. A két ellátási formáról, illetve a kombinált változatokról, mint a 
Copenhagen-koncepció [63], valamint az előnyökről és hátrányokról további vizsgálatok szükségesek.

Nemcsak a traumás eseteket, hanem a perioperatív vérzések teljes skálájának ellátását felölelő európai irányelv [64] az említett vonatkozásokban megegyezik a legújabb traumatológiai irányelvvel. A 2012-ben készült és 2013-ban a Magyar Aneszteziológiai és Intenzív Terápiás Szakmai Kollégium által készített, jóváhagyott és az Egészségügyi Szakmai Kollégium más érintett tagozatai által elfogadásra került, jelenleg érvényes magyar egészségügyi szakmai irányelv az „Életveszélyes perioperatív vérzések ellátásáról” [29] a tárgyalt kérdésekben összhangban van az utána megjelent európai traumás, illetve általános perioperatív ajánlásokkal. Ezek közül is kiemelendő a megjelenésekor újdonságértékkel bíró, illetve vita tárgyát képező korai fibrinogénadás FFP-vel vagy a nélkül, meghagyva az igazán magas formulavezérelt RBC : FFP : THR 1 : 1 : l arányt a klinikai helyzettől "kontextszenzitív" módon alkalmazni, amennyiben nagy a beteg volumenvesztése, és/vagy fibrinogénkészítmény nem érhető el $[29,65]$. Ugyancsak nagy hangsúlyt kapott a magyar irányelvben a VHA-k alkalmazása és a korai célvezérelt, diagnosztikus és terápiás elemeket tartalmazó, „teranosztikus” haemostaticus kezelés mint elméleti és gyakorlati, taktikai és stratégiai célkitűzés [29]. A periodikus megújítás előtt álló, „Életveszélyes perioperatív vérzések ellátása” magyar egészségügyi szakmai irányelv ajánlásai egyeznek az allogén transzfúziós igény csökkentésére irányuló európai törekvésekkel.

\section{A korai célvezérelt haemostasisresuscitatio - nemzetközi eredmények}

A viszkoelasztikus koagulációs POC-tesztek használatával csökkenthetôvé vált a perioperatív vérzés és allogén transzfúziós igény szívsebészeti $[49,66]$, traumatológiai [67], ortopédiai [68] mútétek során és peripartum vérzések ellátása alkalmával [69]. Az eredményeket a közelmúltban tematikus áttekintő közlemény és metaanalízis erősítette meg $[70,71]$. Faktorkoncentrátumok alkalmazásával hasonlóképpen csökkenthetôvé vált a perioperatív vérzés és a transzfúzió szívsebészeti $[9,49,66,72]$, érsebészeti [73], szülészeti [74] és traumatológiai [67] beavatkozások során. Az adatokat egy metaanalízis is alátámasztotta, a fibrinogénkoncentráció hatásosnak bizonyult a transzfúziós igény csökkentésére [42]. Az irodalomban találunk ugyanakkor néhány ellentmondó adatot. Egy szívsebészeti prospektív, randomizált, kontrollált vizsgálat (PRCT) paradox módon nagyobb vérzést talált cardiopulmonalis bypass $(\mathrm{CPB})$ után alkalmazott fibrinogént követően. A nem várt eredmény mögött módszertani okok állhattak. Mind az intervenciós, mind a kontrollcsoport fibrinogénplazma-szintje normális volt a gyógyszer alkalmazása előttt, és a fibrinogén adásának kritériuma a CPB-ről leállás utáni 5 perc alatti vérzés mennyisége volt, mely jórészt sebészi vérzési viszonyokat tükrözhetett [75]. Egy másik, a fibrinogén hatásosságát peripartum vérzésben vizsgáló PRCT szerint nem volt különbség az 1,5 liter vérzést követően alkalmazott fibrinogénnel és placebóval kezelt csoport között, de a tradicionális vizsgálatok utólagosan mindkét populációban egyforma, a terhesekben fiziológiás fibrinogénvérszintet $(>4 \mathrm{~g} / \mathrm{l})$ mutattak. Ezek a betegek tehát nem hiánypótlásra, hanem fölöslegesen kapták az intervenciós gyógyszert, ami a hatás elmaradásának okát is magyarázhatja [48]. A fibrinogén vérző betegben történő első vonalbeli használatáról a Perioperatív Haemostasis Frankofon Munkacsoportja által a közelmúltban kiadott szakértői állásfoglalás szerint a fibrinogénkoncentrátum adása megelôző céllal, tehát primer prevencióra nem ajánlott, alkalmazása súlyos, aktív vérzésre korlátozódik. Monitorozása javasolt, a koncentrációjának meghatározását célzó tradicionális teszttel vagy a funkcionális fibrinogén becslésére irányuló, betegágy melletti VHA segítségével. Ez utóbbi gyorsabb, és figyelembe veszi a fibrinolízis hatását is, hiszen ez nemcsak a fibrint, hanem a saját vagy már a farmakológiai eredetû́ exogén fibrinogént is gátolja. Adása mindenképp javasolt, ha a fibrinogénkoncentráció $<1,5 \mathrm{~g} / \mathrm{l}$, vagy ha a VHA-tesztek szerint fibrinogéndeficit áll fenn. Dózisa $25-50 \mathrm{mg} / \mathrm{kg}$ vagy $4 \mathrm{~g}$ [76].

\section{A korai célvezérelt haemostasisresuscitatio- magyarországi gyakorlat}

Magyarországon az összes nemzetközi, illetve magyar irányelvben ajánlott alvadásaktív stabil készítmény rutinszerúen megrendelhető és elérhető a klinikai gyakorlat számára. Jelenleg folyik a kórházakban egy ismert, központi helyen tárolt, mindenkor azonnal elérhető, aláirói fegyelemmel rendszeresen utántöltött, életmentő készenléti haemostaticus gyógyszerkészlet kialakítása. Ennek a célratörő, gazdaságos és rugalmas gyakorlatnak az általánossá tétele kívánatos lenne.

Az egész magyar fekvőbeteg-ellátásban 2013-ban még csak egy helyen múködött rendszeresen betegágy melletti viszkoelasztikus haemostaticus monitorozás, a többi intézetben tradicionális véralvadási tesztek álltak rendelkezésre, melyek az életveszélyes perioperatív vérzések klinikai szituációjában korlátozott értékúek, mert hiányos fiziológiás mozaikképet adnak jelentős időbeli késéssel. Az azóta eltelt öt évben viszont jelentős előrelépés történt: jelenleg mintegy 30 mútőasztal/betegágy melletti viszkoelasztikus haemostaticus monitor múködik az országban (személyes közlés). A fejlesztésekben nagy szerepe volt az idegen vért lelkiismereti okokból elutasító betegek önsegélyező szervezetének is.

Magyarországon 2013 óta elérhető az életveszélyes perioperatív vérzések ellátására vonatkozó hazai irányelv, mely megújítás előtt áll, de minden fó pontban jelenleg is összhangban van az érvényes, hasonló nemzetközi dokumentumokkal $[5,29,64]$. Mivel a magyar irányelv 2013-ban témájában új volt, kiegészítő edukációs infor- 
mációval is próbálta segíteni a felhasználókat. Az irányelv anyaga bekerült a 2014-ben megújított magyar aneszteziológiai és intenzív terápiás tankönyvbe, ezzel ismerete szakvizsga-követelménnyé vált.

A Magyar Aneszteziológiai és Intenzív Terápiás Társaság szakmai és szervezeti keretein belül 2013-ban megalakult a Perioperatív Haemostasis Szekció, mely az elmúlt öt évben nyolc alkalommal kétnapos, elméleti képzést és múhelygyakorlatot egyaránt tartalmazó posztgraduális tanfolyamot tartott a perioperatív haemostasis kérdéseiről. Ezeket a képzési formákat mintegy 15 egynapos elméleti tanfolyam, valamint állandó kongresszusi megjelenés egészítette ki. Az eddigi tanfolyamokon és a kongresszusi továbbképző előadásokon 1194 részt vevő orvos regisztrált. Fontos, hogy nemcsak aneszteziológusok, hanem sebészek, traumatológusok, nőgyógyászok, transzfuziológusok, hematológusok is részt vettek, mind előadóként, mind hallgatóként. Egy 2017-es kétnapos tanfolyam már címében is hordozta az interdiszciplináris jelleget és célokat. Több alkalommal nővérek, asszisztensek számára is volt elérhető szervezett tanfolyam. Magyarországon a haemostasis kritikus perioperatív kérdéseiben jártas szakembergárda kiépítése ezzel megindult, és folyamatos.

\section{Szakmai kihívás: vérkészítmény-ellátási nehézségek}

Az előbbiekben részletezett okok fontos szerepet játszottak abban, hogy az allogén transzfúziós készítmények felhasználása a fejlett egészségügyi rendszerrel rendelkező országokban az elmúlt 10 évben folyamatosan csökkent. Ugyanakkor, ezzel közel egy időben, a véradási hajlandóság viszonylagos állandóságát társadalmi és világméretekben erőteljes csökkenés váltotta fel [16, 17, 77]. Az Amerikai Egyesült Államokban ez a tendencia azóta is folyamatos, és a vérdonáció csökkenésének üteme meghaladja a felhasználás csökkenésének tempóját (2. ábra)! A jelen folyamatok fennállása esetén a következő évtized közepére a ténylegesen transzfúzióra kerülő - tehát nem is a szolgálatok által kiadott - vörösvérsejtmassza-igény mennyisége így feltehetőleg meghaladja a jelen tendenciákból számítható rendelkezésre álló készletet $[16,17,77]$. Nehezíti a megfelelő vérmennyiség biztosítását az interferencia a térítéses vérkomponens (plazma)-donációval és a szabadságos periódusokhoz kötött szezonalitás. A megfelelő, rendszerszintü vérellátás nehézségeit fokozhatja, hogy az idős betegek egyre nagyobb számban jelentkező degeneratív betegségei, illetve azok sebészi és belgyógyászati ellátása miatt a felhasználás várhatólag újra növekedésnek indul [77]. A fenyegető ellátási probléma miatt az egészségügyi ellátórendszerek lépéskényszerbe kerültek. A vérellátó szolgálatok, így a magyarországi is, átgondolt és rendkívül erőteljes lépéseket tesznek a donációnövelésre, például donortoborzás az új nemzedékekre adaptált, új típusú kommunikációval, a donor-egészségfelügyelet

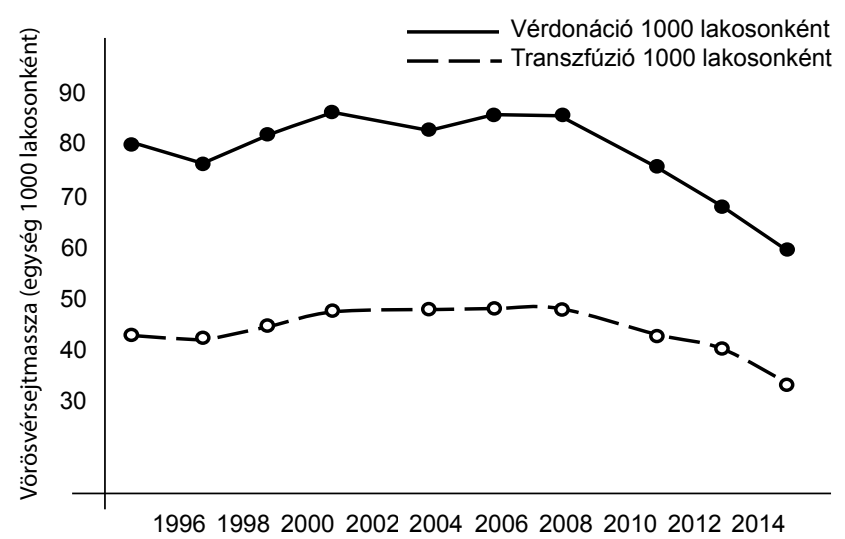

2. ábra

A véradási aktivitásban az Amerikai Egyesült Államokban 2008 óta jelentős visszaesés mutatkozik, és ennek üteme a transzfúzióra került allogén készítmények számában tapasztalható csökkenést meghaladja! A tendenciák változatlansága esetén ezek a folyamatok a következó évtized közepére komoly transzfúziós ellátási nehézséget okozhatnak, vagy előrevetítik a transzfúziós készítmények árának erőteljes növekedését. A kedvezőtlen trend megállítása a vérellátó szolgálatoknak és a betegellátó intézményeknek most lépéskényszert, pár év múlva már kényszerlépést okozhat. Míg az előbbi esetén még vannak választási lehetőségek, az utóbbi esetén más csak a „damage-control betegellátási logisztika” érvényesülhet

erősítése vagy a donor-készítmény-recipiens útvonal lehető legészszerúbb megszervezése. A felhasználói, perioperatív oldal a PBM komplex stratégiájának és taktikájának alkalmazásával veheti ki részét a vérkészítmény-ellátás egyensúlyvesztésének megelőzéséből, hiszen ez beláthatatlan, rendkívül súlyos szakmai, gazdasági és társadalmi feszültségeket generálna. Ezekbe a törekvésekbe illesztendő be az életveszélyes periprocedurális vérzések hazai ellátási hangsúlyainak ultimátumszerú felzárkóztatása a mai nemzetközi trendekhez, mely csökkentheti a kampányszerú, egy-egy vércsoportot és nagy mennyiséget érintő, a lokális biztonsági készletet mindenkor veszélyeztető vérfelhasználást. Ez azonban fontos logisztikai és financiális teendőket tesz szükségessé.

\section{Logisztikai, financiális kihívás}

Magyarországon a faktorkészítmények használata 2011 ben még nagyságrendi lemaradást mutatott a környezetünkben lévő, fejlett egészségügyi rendszerrel rendelkező országok alvadásaktív stabil faktorkoncentrátum-felhasználásához képest, de a hazánkkal összemérhető gazdasági potenciált, szociális szervezettséget képviselő országokkal szemben is jelentős volt a hátrányunk (2. táblázat). Az elmúlt pár évben a perioperatív haemostasis hazai szakmai, tárgyi fejlődése révén a szakmai irányelvkövetés a klinikai gyakorlatban javult, következésképpen nőtt a faktorkoncentrátum-használat aránya, de ezen a téren sajnos még jelentősek az elmaradások a nemzetközi gyakorlathoz képest (2. táblázat). 
2. táblázat $\mid$ Az egy év alatt elhasznált fibrinogén egész országra vonatkoztatott abszolút és 100000 lakosra számított, grammban kifejezett mennyisége 2011-ben, Magyarországon nagyságrendi elmaradást mutatott a fejlettebb egészségüggyel rendelkező európai országokhoz képest. A hozzánk közelebb álló Csehországot minimálisan megelőztük, de Szlovénia fibrinogénfelhasználása számottevő mértékben meghaladta hazánkét. 2017-ben az említett adatok jelentős magyarországi fejlődésről tesznek tanúbizonyságot, elmaradásunk azonban még így is számottevő

\begin{tabular}{|c|c|c|c|c|c|c|c|}
\hline & \multicolumn{3}{|c|}{2011} & \multicolumn{3}{|c|}{2017} & \multirow[b]{2}{*}{ Növekedés (\%) } \\
\hline Ország & $\begin{array}{c}\text { Fibrinogén } \\
\text { (g/év) }\end{array}$ & $\begin{array}{c}\text { Fibrinogén } \\
\text { (g/év/100 } 000 \\
\text { lakos) }\end{array}$ & $\begin{array}{c}\text { Viszony } \\
\text { a magyar } \\
\text { felhasználáshoz }\end{array}$ & $\begin{array}{c}\text { Fibrinogén } \\
\text { (g/év) }\end{array}$ & $\begin{array}{c}\text { Fibrinogén } \\
\text { (g/év/100 } 000 \\
\text { lakos) }\end{array}$ & $\begin{array}{c}\text { Viszony } \\
\text { a magyar } \\
\text { felhasználáshoz }\end{array}$ & \\
\hline Ausztria & 37334 & 442 & $40 \times$ & 43000 & 509 & $8,3 \times$ & 15 \\
\hline Svájc & 27351 & 348 & $31 \times$ & 28000 & 356 & $5,8 \times$ & 2 \\
\hline Németország & 180877 & 221 & $20 \times$ & 230000 & 281 & $4,6 \times$ & 27 \\
\hline Csehország & 912 & 9 & $0,8 \times$ & 18445 & 176 & $2,8 \times$ & 1922 \\
\hline Szlovénia & 3026 & 56 & $5 \times$ & 4678 & 87 & $1,4 \times$ & 55 \\
\hline Magyarország & 1100 & 11 & - & 6039 & 61 & - & 449 \\
\hline
\end{tabular}

A fejlődés akadályát jelenleg az életveszélyes vérzésekben szenvedő betegek ellátásának elavult finanszírozási struktúrája képezi. Jelenleg az életveszélyes vérzésekben, sokszor gyógyítható alapbetegségben szenvedő betegek, esetleg kismamák ellátásához szükséges allogén transzfúziós készítményeket, vörösvérsejt-szuszpenziót, friss fagyasztott plazmát, esetleg thrombocytakészítményeket az Országos Vérellátó Szolgálat precízen és a lehetőségekhez képest gyorsan, néha minden erejét megfeszítve, de rendelkezésre bocsátja, és minden fekvőbeteg-ellátó intézmény ennek árát utána „gondolkodás nélkül”, quantum satis kifizeti. Majd a masszív transzfúzió által keltett szövődmények, mint a megnyúlt lélegeztetés, vesepótló kezelés, antibiotikumterápia, sebgyógyulási zavarok költségeit is fedezi. Az ellátórendszernek ezeken kívül tudomásul kell vennie a kényszerüségből lecsökkent betegáramlást is, tehát például le kell mondania a más elektív betegek mútétje által megtermelt HBCS-bevételről. A fekvőbeteg-ellátó intézmények ugyanakkor kénytelenek adminisztratív eszközökkel restrikciót gyakorolni a korszerú faktorkészítmények rendelésekor, hiszen az intézményi/intézeti gyógyszerellátás anyagi keretei a stabil alvadásaktív készítmények magyarországi elterjedése előtt lettek beállítva. A rendelkezésre álló keretek rendszeres gondozása fóként az eddigi terápiás rezsimek ármozgásait hivatott fedezni; a kiigazítások révén a fekvőbeteg-ellátó intézmények költségvetése csak minimális mértékben képes jelenleg az alvadásaktív stabil faktorkészítményeket befogadni.

A megoldást keresve, a szakmai gyógyító célok és lehetőségek ellentmondását kézenfekvő lenne forráshiányra egyszerúsíteni. Ez csak részben igaz az életveszélyes periprocedurális vérzések ellátása során. Megvalósítható és racionális megoldásnak tűnik viszont a fekvőbeteg-intézmények meglévő forrásainak felhasználását rugalmasabbá tenni. Ennek lényege, hogy meg kellene teremteni az allogén vérkészítményekre allokált igen jelentős pénzösszeg és a stabil véralvadási készítményekre fordított, eddig élesen elkülönített pénzösszeg közötti átjárhatóságot! Ezzel meg lehet adni a lehetőséget a már képzett és kellő monitorozás birtokában lévő perioperatív orvos számára, hogy döntsön az „ott és akkor” legjobb terápiáról. Hogy faktorkészítmény-alapú vagy allogén készítményekre támaszkodó terápiát végez egy adott esetben, illetve annak bizonyos szakaszában. Ennek a döntésnek a meghozatalához a perioperatív életmentést végző orvosok döntő többségének vagy a hátterét képező kollégáinak ma minden eszköz a kezében van! A faktorkészítmények költségeit a megtakarított allogén vérkészítmények költségei ellensúlyozzák. További, gazdasági számításokat igénylő előnyöket jelenthet a masszív transzfúzió szövődményeinek kezelésére fordított pénz, idő, emberi erő csökkenése [78]. Németországi vizsgálatokban a korai-célorientált haemostasisresuscitatio költséghatékonynak bizonyult $[37,79,80]$.

\section{Következtetések}

Az életveszélyes perioperatív vérzések sokszor egészséges fiatalokat sodornak pillanatok alatt szerv- vagy életvesztés közvetlen közelébe baleset vagy szülés kapcsán, vagy gyógyítható alapbetegségben szenvedő szív-, érsebészeti betegek és családtagjaik számára jelenítik meg a rövid és hosszú távú multiplex szövődmények és elhalálozás közvetlen veszélyét. A ,from bench to bedside” ismeretek elterjedése és tankönyvekben, irányelvekben történő intézményesítése után az ellátórendszeren a sor, hogy megteremtse az alkalmazás másik, ,from bank to bedside” aspektusát, tehát a finanszírozás biztos, kiszámítható, rendszerszintű hátterét. De fordíthatjuk tovább is a szót magára a vérre, a vérbankra is.

Álláspontunk szerint az életveszélyes perioperatív vérzések ellátásához az utóbbi években kapcsolódó diagnosztikus és terápiás modalitások csak részben igényelnek ehhez allokált új erőforrásokat. Az anyagi erőforrásokat részlegesen biztosíthatná a meglévő anyagi erők flexibilitásának növelése. Ha az allogén készítményekre, valamint a faktorkoncentrátumra fordítható pénzügyi keretek intézeti/intézményi szinten, de országos szervezettséggel átjárhatóvá válnának, akkor a friss-fagyasztott 
plazma megtakarítása, valamint a nagy mennyiségú allogén plazma használatán alapuló haemostasisresuscitatio szövődményeinek megelőzése megteremtené a faktorkoncentrátumok első vonalbeli használatának anyagi lehetőségét.

A változtatások lehetővé tennék perioperatív kezelőorvosaink számára, hogy az élenjáró nemzetközi gyakorlatnak megfelelő betegellátást végezzenek, melyet tőlük a Magyar Aneszteziológiai és Intenzív Terápiás Társaság Szakmai Kollégiuma által jóváhagyott multidiszciplináris EMMI egészségügyi szakmai irányelv, képzési és szakvizsga-követelmények el is várják. Ennél is fontosabb természetesen az az additív társadalmi elvárás, hogy a súlyos életveszélyes vérzésekben szenvedő betegek, különösen balesetes fiatalemberek és szülő kismamák, a jelenleg javasolt, leghatékonyabb ellátást kaphassák meg késlekedés nélkül Magyarországon is. Szélesebb kontextusba helyezve fontos lehet még a jól ismert szakmai standardoktól eltérő működés káros hatásainak (kiégés, perköltségek) kivédése vagy a várhatóan megtakarított több tízezer friss-fagyasztott plazma esetleges profitorientált feldolgozásából származó haszon.

Fülünkben cseng a jól ismert szlogen: „Aki vért ad, életet ad!" Érvényességéhez nem férhet kétség, de ideje más aspektusból is értelmezni az orvosi segítségnyújtás alapvető attitűdjét: „Aki vért ment, életet ment.” Ha másért nem is, hát azért, hogy maradjon még másnak mit adni a jövőben is.

Anyagi támogatás: A szerzők anyagi támogatásban nem részesültek.

Szerzôi munkamegosztás: A szerzők az irodalomgyüjtésben, a kézirat és az ábrák elkészítésében és az egyes fejezetek előkészítésében egyaránt részt vettek. A cikk végleges változatát valamennyien elolvasták és jóváhagyták.

Érdekeltségek: A szerzőknek nincsenek érdekeltségeik.

\section{Irodalom}

[1] Vuylsteke A, Pagel C, Gerrard C, et al. The Papworth Bleeding Risk Score: a stratification scheme for identifying cardiac surgery patients at risk of excessive early postoperative bleeding. Eur J Cardiothorac Surg. 2011; 39: 924-930.

[2] Thiele RH, Raphael J. A 2014 update on coagulation management for cardiopulmonary bypass. Semin Cardiothorac Vasc Anesth. 2014; 18: 177-189.

[3] Karkouti K, Callum J, Wijeysundera DN, et al. Point-of-care hemostatic testing in cardiac surgery. A stepped-wedge clustered randomized controlled trial. Circulation 2016; 134: 1152-1162.

[4] Curry N, Hopewell S, Dorée C, et al. The acute management of trauma hemorrhage: a systematic review of randomized controlled trials. Crit Care 2011; 15: R92.

[5] Rossaint R, Bouillon B, Cerny V, et al. The European guideline on management of major bleeding and coagulopathy following trauma: fourth edition. Crit Care 2016; 20: 100.

[6] Knapp J, Hofer S, Lier H. Anesthesiological approach to postpartum hemorrhage. Anaesthesist 2016; 65: 225-240.
[7] Joseph KS, Rouleau J, Kramer MS, et al. Investigation of an increase in postpartum haemorrhage in Canada. BJOG 2007; 114: 751-759.

[8] Besser MW, Ortmann E, Klein AA. Haemostatic management of cardiac surgical haemorrhage. Anaesthesia 2015; 70(Suppl 1): 87-95. e29-e31.

[9] Görlinger K, Fries D, Dirkmann D, et al. Reduction of fresh frozen plasma requirements by perioperative point-of-care coagulation management with early calculated goal-directed therapy. Transfus Med Hemother. 2012; 39: 104-113.

[10] Christensen MC, Dziewior F, Kempel A, et al. Increased chest tube drainage is independently associated with adverse outcome after cardiac surgery. J Cardiothorac Vasc Anesth. 2012; 26: 46-51.

[11] Christensen MC, Krapf S, Kempel A, et al. Costs of excessive postoperative hemorrhage in cardiac surgery. J Thorac Cardiovasc Surg. 2009; 138: 687-693.

[12] Campbell HE, Stokes EA, Bargo DN, et al. Quantifying the healthcare costs of treating severely bleeding major trauma patients: a national study for England. Crit Care 2015; 19: 276.

[13] Shem Tov L, Matot I. Frailty and anesthesia. Curr Opin Anaesthesiol. 2017; 30: 409-417.

[14] Kálmán S, Pákáski M, Kálmán J. Frailty syndrome: an old new friend. [Esendőségszindróma: egy régi új ismerôs.] Orv Hetil. 2014; 155: 1935-1951. [Hungarian]

[15] Babik B, Peták F, Agócs S, et al. Diabetes mellitus: endothelial dysfunction and changes in hemostasis. [Diabetes mellitus: endotheldiszfunkció és haemostasiselváltozások.] Orv Hetil. 2018; 159: 1335-1345. [Hungarian]

[16] Ellingson KD, Sapiano MR, Haass KA, et al. Continued decline in blood collection and transfusion in the United States - 2015. Transfusion 2017; 57(Suppl 2): 1588-1598.

[17] Whitaker B, Rajbhandary S, Kleinman S, et al. Trends in United States blood collection and transfusion: results from the 2013 AABB Blood Collection, Utilization, and Patient Blood Management Survey. Transfusion 2016; 56: 2173-2183.

[18] Farmer SL, Towler SC, Leahy MF, et al. Drivers for change: Western Australia Patient Blood Management Program (WA PBMP), World Health Assembly (WHA) and Advisory Committee on Blood Safety and Availability (ACBSA). Best Pract Res Clin Anaesthesiol. 2013; 27: 43-58.

[19] Arora RC, Brown CH 4th, Sanjanwala RM, et al. "NEW" prehabilitation: a 3-way approach to improve postoperative survival and health-related quality of life in cardiac surgery patients. Can J Cardiol. 2018; 34: 839-849.

[20] Furie B, Furie BC. Mechanisms of thrombus formation. N Engl J Med. 2008; 359: 938-949.

[21] Hiippala ST, Myllylä GJ, Vahtera EM. Hemostatic factors and replacement of major blood loss with plasma-poor red cell concentrates. Anesth Analg. 1995; 81: 360-365.

[22] Chambers LA, Chow SJ, Shaffer LE. Frequency and characteristics of coagulopathy in trauma patients treated with a low- or high-plasma-content massive transfusion protocol. Am J Clin Pathol. 2011; 136: 364-370.

[23] Davenport R, Manson J, De'Ath H, et al. Functional definition and characterization of acute traumatic coagulopathy. Crit Care Med. 2011; 39: 2652-2658.

[24] Schöchl H, Cotton B, Inaba K, et al. FIBTEM provides early prediction of massive transfusion in trauma. Crit Care 2011; 15: R265.

[25] Bruce D, Nokes TJ. Prothrombin complex concentrate (Beriplex $\mathrm{P} / \mathrm{N}$ ) in severe bleeding: experience in a large tertiary hospital. Crit Care 2008; 12: R105.

[26] Fenger-Eriksen C, Ingerslev J, Sørensen B. Fibrinogen concentrate - a potential universal hemostatic agent. Expert Opin Biol Ther. 2009; 9: 1325-1333.

[27] Rahe-Meyer N, Sørensen B. Fibrinogen concentrate for management of bleeding. J Thromb Haemost. 2011; 9: 1-5. 
[28] Velik-Salchner C, Haas T, Innerhofer P, et al. The effect of fibrinogen concentrate on thrombocytopenia. J Thromb Haemost. 2007; 5: 1019-1025.

[29] Babik B, Fazakas J. (eds). Management of severe perioperative bleeding. [Az életveszélyes perioperatív vérzések ellátása. A Magyar Aneszteziológiai és Intenzív Terápiás Társaság szakmai irányelve, 2013.] [Hungarian]

[30] Pabinger I, Brenner B, Kalina U, et al. Prothrombin complex concentrate (Beriplex $\mathrm{P} / \mathrm{N}$ ) for emergency anticoagulation reversal: a prospective multinational clinical trial. J Thromb Haemost. 2008; 6: 622-631.

[31] Levy JH, Tanaka KA, Dietrich W. Perioperative hemostatic management of patients treated with vitamin $\mathrm{K}$ antagonists. Anesthesiology 2008; 109: 918-926.

[32] Samama CM. Prothrombin complex concentrates: a brief review. Eur J Anaesthesiol. 2008; 25: 784-789.

[33] Fenger-Eriksen C, Lindberg-Larsen M, Christensen AQ, et al. Fibrinogen concentrate substitution therapy in patients with massive haemorrhage and low plasma fibrinogen concentrations. Br J Anaesth. 2008; 101: 769-773.

[34] Stinger HK, Spinella PC, Perkins JG, et al. The ratio of fibrinogen to red cells transfused affects survival in casualties receiving massive transfusions at an army combat support hospital. J Trauma 2008; 64: S79-S85; discussion S85.

[35] Schöchl H, Nienaber U, Hofer G, et al. Goal-directed coagulation management of major trauma patients using thromboelastometry (ROTEM)-guided administration of fibrinogen concentrate and prothrombin complex concentrate. Crit Care 2010; 14: R55.

[36] Rahe-Meyer N, Hanke A, Schmidt DS, et al. Fibrinogen concentrate reduces intraoperative bleeding when used as first-line hemostatic therapy during major aortic replacement surgery: results from a randomized, placebo-controlled trial. J Thorac Cardiovasc Surg. 2013; 145: S178-S185.

[37] Weber CF, Görlinger K, Meininger D, et al. Point-of-care testing: a prospective, randomized clinical trial of efficacy in coagulopathic cardiac surgery patients. Anesthesiology 2012; 117: $531-547$.

[38] Solomon C, Pichlmaier U, Schoechl H, et al. Recovery of fibrinogen after administration of fibrinogen concentrate to patients with severe bleeding after cardiopulmonary bypass surgery. Br J Anaesth. 2010; 104: 555-562.

[39] Rahe-Meyer N, Solomon C, Hanke A, et al. Effects of fibrinogen concentrate as first-line therapy during major aortic replacement surgery: a randomized, placebo-controlled trial. Anesthesiology 2013; 118: 40-50.

[40] Wikkelsø AJ, Edwards HM, Afshari A, et al. Pre-emptive treatment with fibrinogen concentrate for postpartum haemorrhage: randomized controlled trial. Br J Anaesth. 2015; 114: 623-633.

[41] Ranucci M, Baryshnikova E. Fibrinogen supplementation after cardiac surgery: insights from the Zero-Plasma trial (ZEPLAST). Br J Anaesth. 2016; 116: 618-623.

[42] Wikkelsø A, Lunde J, Johansen M, et al. Fibrinogen concentrate in bleeding patients. Cochrane Database Syst Rev. 2013; 8: CD008864.

[43] Aubron C, Reade MC, Fraser JF, et al. Efficacy and safety of fibrinogen concentrate in trauma patients - a systematic review. J Crit Care 2014; 29: 471.el1-471.el7.

[44] Lunde J, Stensballe J, Wikkelsø A, et al. Fibrinogen concentrate for bleeding - a systematic review. Acta Anaesthesiol Scand. 2014; 58: 1061-1074.

[45] Solomon C, Gröner A, Ye J, et al. Safety of fibrinogen concentrate: analysis of more than 27 years of pharmacovigilance data. Thromb Haemost. 2015; 113: 759-771.

[46] Hellstern P. Production and composition of prothrombin complex concentrates: correlation between composition and therapeutic efficiency. Thromb Res. 1999; 95(Suppl 1): S7-S12.
[47] Vigué B, Ract C, Tremey B, et al. Ultra-rapid management of oral anticoagulant therapy-related surgical intracranial hemorrhage. Intensive Care Med. 2007; 33: 721-725.

[48] Schulman S, Bijsterveld NR. Anticoagulants and their reversal. Transfus Med Rev. 2007; 21: 37-48.

[49] Bolliger D, Tanaka KA. Point-of-care coagulation testing in cardiac surgery. Semin Thromb Hemost. 2017; 43: 386-396.

[50] Luddington RJ. Thrombelastography/thromboelastometry. Clin Lab Haematol. 2005; 27: 81-90.

[51] Grottke O, Henzler D, Spahn DR, et al. Coagulopathy in multiple trauma: new aspects of therapy. Anaesthesist 2007; 56: 95106; quiz 107-108.

[52] Schöchl H, Maegele M, Solomon C, et al. Early and individualized goal-directed therapy for trauma-induced coagulopathy. Scand J Trauma Resusc Emerg Med. 2012; 20 : 15.

[53] Kozek-Langenecker S. Management of massive operative blood loss. Minerva Anestesiol. 2007; 73: 401-415.

[54] Briggs C, Guthrie D, Hyde K, et al. Guidelines for point-of-care testing: haematology. Br J Haematol. 2008; 142: 904-915.

[55] Levrat A, Gros A, Rugeri L, et al. Evaluation of rotation thrombelastography for the diagnosis of hyperfibrinolysis in trauma patients. Br J Anaesth. 2008; 100: 792-797.

[56] Spahn DR, Rossaint R. Coagulopathy and blood component transfusion in trauma. Br J Anaesth. 2005; 95: 130-139.

[57] Spahn DR, Cerny V, Coats TJ, et al. Management of bleeding following major trauma: a European guideline. Crit Care 2007; 11: R17.

[58] Rossaint R, Bouillon B, Cerny V, et al. Management of bleeding following major trauma: an updated European guideline. Crit Care 2010; 14: R52.

[59] Spahn DR, Bouillon B, Cerny V, et al. Management of bleeding and coagulopathy following major trauma: an updated European guideline. Crit Care 2013; 17: R76.

[60] Holcomb JB, Wade CE, Michalek JE, et al. Increased plasma and platelet to red blood cell ratios improves outcome in 466 massively transfused civilian trauma patients. Ann Surg. 2008; 248: 447-458.

[61] Kashuk JL, Moore EE, Johnson JL, et al. Postinjury life threatening coagulopathy: is $1: 1$ fresh frozen plasma:packed red blood cells the answer? J Trauma 2008; 65 : 261-270; discussion 270 271.

[62] Teixeira PG, Inaba K, Shulman I, et al. Impact of plasma transfusion in massively transfused trauma patients. J Trauma 2009; 66: 693-697.

[63] Stensballe J, Henriksen HH, Johansson PI. Early haemorrhage control and management of trauma-induced coagulopathy: the importance of goal-directed therapy. Curr Opin Crit Care 2017; 23: $503-510$

[64] Kozek-Langenecker SA, Ahmed AB, Afshari A, et al. Management of severe perioperative bleeding: guidelines from the European Society of Anaesthesiology: First update 2016. Eur J Anaesthesiol. 2017; 34: 332-395.

[65] Babik B. Hemostasis in pregnancy: a natural model of hemostasis. Resuscitation in patients with massive perioperative blood loss. [A véralvadási rendszer adaptációja terhességben: a hemosztázisreszuszcitáció természetes modellje masszív vérzésben. Aneszteziol Int Ter. 2017; 47: 9-23. [Hungarian]

[66] Baryshnikova E, Ranucci M. Point-of-care haemostasis and coagulation monitoring in cardiac surgery at IRCCS Policlinico San Donato. Eur Heart J Suppl. 2016; 18(Suppl E): E42-E48.

[67] Brohi KE, Eaglestone S. Traumatic coagulopathy and massive transfusion: improving outcomes and saving blood. Programme Grants for Applied Research 5: 19. Southampton (UK), NIHR Journals Library, November 2017.

[68] Naik BI, Pajewski TN, Bogdonoff DI, et al. Rotational thromboelastometry-guided blood product management in major spine surgery. J Neurosurg Spine 2015; 23: 239-249. 
[69] Solomon C, Collis RE, Collins PW. Haemostatic monitoring during postpartum haemorrhage and implications for management. Br J Anaesth. 2012; 109: 851-863.

[70] Fahrendorff M, Oliveri RS, Johansson PI. The use of viscoelastic haemostatic assays in goal-directing treatment with allogeneic blood products - A systematic review and meta-analysis. Scand J Trauma Resusc Emerg Med. 2017; 25: 39.

[71] Wikkelsø A, Wetterslev J, Møller AM, et al. Thromboelastography (TEG) or rotational thromboelastometry (ROTEM) to monitor haemostatic treatment in bleeding patients: a systematic review with meta-analysis and trial sequential analysis. Anaesthesia 2017; 72: 519-531.

[72] Tang M, Fenger-Eriksen C, Wierup P, et al. Rational and timely haemostatic interventions following cardiac surgery - coagulation factor concentrates or blood bank products. Thromb Res. 2017; 154: 73-79.

[73] Chee YE, Liu SE, Irwin MG. Management of bleeding in vascular surgery. Br J Anaesth. 2016; 117(Suppl 2): ii85-ii94.

[74] Neb H, Zacharowski K, Meybohm P. Strategies to reduce blood product utilization in obstetric practice. Curr Opin Anaesthesiol. 2017; 30: 294-299.

[75] Rahe-Meyer N, Levy JH, Mazer CD, et al. Randomized evaluation of fibrinogen vs placebo in complex cardiovascular surgery (REPLACE): a double-blind phase III study of haemostatic therapy. Br J Anaesth. 2016; 117: 41-51.

[76] Samama CM, Ickx B, Ozier Y, et al. The place of fibrinogen concentrates in the management of perioperative bleeding: a posi- tion paper from the Francophone Working Group on Perioperative Haemostasis (GIHP). Anaesth Crit Care Pain Med. 2018; 37: 355-365.

[77] Williamson LM, Devine DV. Challenges in the management of the blood supply. Lancet 2013; 381: 1866-1875.

[78] Udvardy M. A new era of transfusion-transmitted pathogens, infections. Renewed need for updating standards for clinicans along with blood banking. [Új korszak és új szempontok a transzfúziós kórokozó-átvitel kockázatában, különös tekintettel a rendszeres plazmaeredetú készítményre szoruló haemophiliás betegekre.] Orv Hetil. 2018; 159: 1495-1500. [Hungarian]

[79] Görlinger K, Dirkmann D, Hanke AA, et al. First-line therapy with coagulation factor concentrates combined with point-ofcare coagulation testing is associated with decreased allogeneic blood transfusion in cardiovascular surgery: a retrospective, single-center cohort study. Anesthesiology 2011; 115: 11791191.

[80] Hanke AA, Herold U, Dirkmann D, et al. Thromboelastometry based early goal-directed coagulation management reduces blood transfusion requirements, adverse events, and costs in acute type A aortic dissection: a pilot study. Transfus Med Hemother. 2012; 39: 121-128.

(Babik Barna dr., Szeged, Semmelweis u. 6., 6720 e-mail: babikbarna@gmail.com)

\title{
"Beatius est dare, quam accipere." (Jobb adni, mint kapni.)
}

\section{Az Orvosi Hetilap 2019, 160, 39. oldalán (1. szám) megjelent OH-Kvízre két helyes megfejtés érkezett.}

\section{A beküldők: Dr. Bíró László (Budapest) és Dr. Pallos Ágnes (Budapest).}

A nyerteseknek szívből gratulálunk.

\author{
A nyereményüket - egy, az Akadémiai Kiadó webáruházában \\ kedvezményes vásárlásra jogosító kupont - e-mailen küldjük el.
}

A cikk a Creative Commons Attribution 4.0 International License (https://creativecommons.org/licenses/by/4.0/) feltételei szerint publikált Open Access közlemény, melynek szellemében a cikk bármilyen médiumban szabadon felhasználható, megosztható és újraközölhető, feltéve, hogy az eredeti szerző és a közlés helye, illetve a CC License linkje és az esetlegesen végrehajtott módosítások feltüntetésre kerülnek. (SID_1) 